\title{
ASCORBIC ACID ADMINISTRATION TRANSPORTATION OF SHEEP \\ AS ANTI-STRESS BEFORE
}

\author{
A. Y. Kassab*¹ and A. A. Mohammed ${ }^{2}$ \\ 1-Department of Animal Production, Faculty of Agriculture, New valley, University of Assiut, 71526, Egypt \\ 2-Department of Animal Production, Faculty of Agriculture, new valley, University of Assiut, 71526, Egypt \\ *Corresponding author: ayman15@yahoo.com
}

\section{SUMMARY}

Currently in Egypt there is no regulation ruling over transportation of animals. The aims of the current study were to investigate the effects of ascorbic acid administration (125 mg/kg) before transportation in an open truck during summer season on live weight loss, and some physiological responses, in New Valley governorate, Egypt. Fourteen Farafra male sheep, $35.0 \pm 3.86 \mathrm{~kg}$ body weight and aged 11-12 months were used in this study. Animals were divided into two equal groups (7/each group) as not-administered and administered ascorbic acid groups. Animals were transported in an open truck covering a distance of approximately $225 \mathrm{~km}$ for three hours. Before loading and after transportation, rectal temperature, respiration rate and pulse rate as thermal responses were recorded. In addition, two blood samples were collected before and after transportation from each animal. Complete blood samples were investigated to determine hematological parameters. Also, blood serum samples were analyzed for hormones (T3, T4 and cortisol) and some blood metabolites (total protein, albumin, globulin, sodium, potassium, chloride, urea, ALT, AST, creatinine, glucose, triglycerides and total cholesterol). The results indicated that transportation caused adverse changes as a results of stress in live body weight losses, hematological parameters and some blood metabolites. Ascorbic acid administration lowered effect of stress caused by transportation through modulating physiological responses. Therefore, administration of ascorbic acid in sheep before transport especially at high ambient temperatures can be recommended.

Keywords: Ascorbic Acid, sheep, transport, physiological responses, stress

\section{INTRODUCTION}

Transportation of livestock in open trucks between farms, markets and slaughterhouses is a routine practice in Egypt. Transportation of animals is generally recognized as a stressful event (Dantzer and Mormede, 1983, Kadim et al., 2007, Minka and Ayo, 2011). In addition, adverse climatic conditions such as temperatures fluctuations and relative humidity are also additional stressors in animals during transportation. Haematological parameters have been demonstrated to be important indices of health, production and adaptability to prevailing environmental conditions in livestock (Adenkola et al., 2009) and also as an indicator of stress in livestock (Adenkola and Durotoye, 2004 and Togun and Oseni, 2005). It has been established that transportation stress has an effect on leucocytosis, with associated lymphopenia, neutrophilia, and eosinopenia (Minka and Ayo, 2007 and Minka and Ayo, 2008). In addition, neutrophil/lymphocyte (N/L) ratio has been used as trustworthy indices in evaluating the immune response and adaptability of animals to various stress conditions (Nwe et al., 1996 and Stanger et al., 2005). Generally, majorities of sheep in tropical regions are reared under extensive management systems and are difficult to handle, and this may increase the level of stress encountered by sheep during rounding up, handling, and loading.

The current management strategies towards alleviation of road transportation stress in animals included the use of analgesic, neuroleptics, electrolytes, or supplementing one or more dietary elements, before, during, or after transportation. Some of these agents are difficult to obtain and apply by the farmers; others are counterproductive, with great consequential effects on both animals and humans, while some have no effect and lack consistency and efficacy (Schaefer et al., 1997; Ali and Al-Qarawi, 2002; Ali et al., 2006 and Ferguson and Warner, 2008). The identification of an additional agent that may be cheaper, nontoxic, with no withdrawal time, and easily to administer would be of value in the field of animal transport.

Ascorbic acid (vitamin C) is known as antioxidant agent and has been widely used to manage stress conditions in animals. (Pardue et al., 1985) reported that under specific environment and physiological conditions, the amount of ascorbic acid produced by the animal may be insufficient to meet its requirement. Under heat stress, free radicals are generated in the body in such a large quantity that the natural antioxidant defense systems of the body are overwhelmed. Therefore, antioxidant supplementation may provide beneficial effect against stress induced tissue damage (Sen, 2001). There is a reasonable body of evidence supporting the use of ascorbic acid in reducing different kind of stresses in animals (Ayo et al., 2006; Ali and AlQarawi, 2002 and Powers and Jackson, 2008).

A little work has been carried out to use or investigate factors that alleviating effects of stress in transported sheep under Egyptian conditions. The aim of the current study was to determine the beneficial effect of administration of ascorbic acid as 
an alleviation suggested factor against road transportation stress in Egyptian sheep.

\section{MATERIALS AND METHODS}

This experiment was carried out in the new valley governorate during summer season. New Valley governorate in Upper Egypt in western desert between $25^{\circ}$; $42 \& 30^{\circ}$; $47 \mathrm{E}$ longitude, $22^{\circ} 30 \& 29^{\circ}$ $30 \mathrm{~N}$ latitude and lies $77.8 \mathrm{~m}$ altitude above the sea level. The climate of this area is arid and dry, essentially that of the desert. Rainfall is almost negligible and the ambient temperature ranges from $46^{\circ} \mathrm{C}$ during summer days to $8^{\circ} \mathrm{C}$ in the chilly winter nights.

\section{Animals and management:}

Fourteen Farafra (local breed in the new valley) male healthy sheep weighting $35.0 \pm 3.86 \mathrm{~kg}$ and aged 11-12 months were used in this study. The sheep were living in a standard sheep pen at a stocking rate of $1.25 \mathrm{~m} 2 /$ sheep. The sheep were not tied inside the pen. The sheep were herded out and grazed daily on a sown pasture from 08:00 a.m to 16:00 p.m. Animals was given access to drinking water ad-libitum. The sown pasture contains trees to provide shade against sunlight.

\section{Experimental design:}

On transportation day, the sheep were numbered, and body weight, rectal temperature, respiration and pulse rate as thermal responses were recorded. Rectal temperature was recorded using a clinical thermometer (Dong E Digital thermometer, Model No: BT-AIICN; LOT NO: 0911 Mad). Respiration rate was recorded with the help of flank movement. Pulse rate was recorded from the coccygeal artery with the help of a stethoscope. Two blood samples before and after transportation from each animal were collected. Thereafter, the sheep were divided into group I oral administered with $125 \mathrm{mg} / \mathrm{kg}$ with ascorbic acid and group II non- administered with ascorbic acid (ADWIC, Pharmaceutical Chemicals Co., Egypt). This dose was slightly higher than that (100 mg/kg) given by Saidu et al. (2012). The dose was dissolved in $10 \mathrm{~mL}$ of sterile water. At the same time, group II were only administered $10 \mathrm{~mL}$ of sterile water orally. Immediately after transportation, the previous thermal responses (rectal temperature, respiration and pulse rate) were recorded and the second blood samples were taken. The obtained both blood samples were analyzed for hematological parameters and some blood metabolites.

The handling, loading, and transportation of sheep were performed humanely in accordance with the guidelines governing animal transport welfare by road (Farm Animal Welfare Council, 2003). The sheep were stocked at a rate of $0.27 \mathrm{~m}^{2}$ per animal inside the vehicle. All the handling and loading of animals were conducted between 11:0 a.m. to 12:0 noon. The floor of the truck was provided with beddings (wood shavings) covered with rubber mats for secured footing. The journey started by 12:00 a.m. and was terminated at 15:00 p.m. The vehicle travelled for $3.00 \mathrm{~h}$. for about $225 \mathrm{~km}$.

\section{Recording air temperature and humidity:}

Air temperature $\left({ }^{\circ} \mathrm{C}\right)$ and humidity (\%) were recorded during the study using Lutron HA-701 DM6016 Multimeter (Taiwan), and hygrometer (GH Zeal Ltdature 8 Deer Park Road Merton London SW19 3UU UK), respectively. Data are presented in Table (1).

Table 1. Air temperature and humidity recoded before and after transportation.

\begin{tabular}{lcc}
\hline Items & $\begin{array}{c}\text { Air } \\
\text { temperature } \\
\left({ }^{\circ} \mathrm{C}\right)\end{array}$ & $\begin{array}{c}\text { Humidity } \\
(\boldsymbol{\%})\end{array}$ \\
\hline $\begin{array}{l}\text { Inside the barn } \\
\begin{array}{l}\text { Before } \\
\text { transportation }\end{array}\end{array}$ & 35.0 & 39.5 \\
After transportation & 44.0 & 30.4 \\
\hline
\end{tabular}

\section{Blood sampling analysis:}

About $10 \mathrm{~mL}$ of blood via jugular venipuncture was collected from each sheep at each period of blood sampling and decanted into two sterile test, one tube with $0.14 \%$ anticoagulant (EDTA K3, Pty Ltd., Adelaide, SA, Australia) for determination hematological parameters, and the other one without anticoagulant for obtaining serum. The collected blood samples were quickly kept in ice pack and sent to the laboratory. Whole blood samples were analyzed for complete blood analysis, while serum samples were obtained by centrifugation of blood samples for 10 minutes at 3,000 r.p.m, then dispensed into $1.5 \mathrm{ml}$ Eppendorf tubes and stored at $-20{ }^{\circ} \mathrm{C}$ for blood metabolites analysis.

Complete blood analysis were determined using sysmex xp-300 ( Japan). Serum samples of all the animals were assayed for cortisol, free triiodothyronine (T3) and free thyroxine (T4) concentrations using radioimmunoassay (RIA) Technique. Total protein, albumin, sodium, potassium, chloride, urea, AST, ALT, glucose, creatinine, cholesterol and triglycerides concentrations were determined using appropriate commercial test kits. The concentrations were measured using standard protocols (Photometer 5010 v5+).

\section{Statistical analysis:}

Data were analyzed using General Linear Model (GLM) procedure of SAS (SAS, 1998) according to the following model:

$\mathrm{Yij}=\mu+\mathrm{Ti}+$ eij

Where: $\mu=$ Mean, $\mathrm{Ti}=$ Effect of treatment and eij= Standard error

Duncan's multiple range test (1955) was used to compare between means of the control and treated groups.

\section{RESULTS}

\section{Body weight loss:}

After 3-h transportation, live body weight losses were $-1.22 \pm 0.18$ and $-0.47 \pm 0.20$ in the two groups. Ascorbic acid administration alleviated live weight 
losses from $3.52 \%$ to $1.33 \%$ in without ascorbic acid and with ascorbic acid groups, respectively but, the differences between the two groups were not significant (Table 2).

\section{Thermal responses:}

Rectal temperature and respiration rate were increased significantly $(\mathrm{P}<0.05)$, while pulse rate was increased non-significantly as a results of transportation (Table 3).

\section{Hematological parameters:}

After the 3-h. transportation, complete blood parameters were changed in the two groups but ascorbic acid administration led to increase red and white blood cells compared to other group (Table 4). Moreover, neutrophils / lymphocyte ratio was nonsignificantly decreased upon ascorbic acid administration.

\section{Blood metabolites:}

Animals after transportation had significantly $(\mathrm{P}<0.05)$ or not significantly increases in the concentrations of cortisol, T3, total protein, potassium, chloride, globulin, urea, creatinine. At the same time Animals after transportation had significantly $(\mathrm{P}<0.05)$ or not significantly decreases on the concentrations of T4, AST, ALT, glucose, triglycerides and cholesterol concentrations than before transportation in both groups (Table 5). Generally, the data indicated that values of blood metabolites in ascorbic acid administration group were lower than other groups Thus, ascorbic acid administration alleviated stress effects of transported sheep through changes in serum metabolites, hormones concentrations.

Table 2. Effect of ascorbic acid administration (mean \pm SEM) on live body weight loss of sheep

\begin{tabular}{lcccc}
\hline Items & \multicolumn{2}{c}{ Without ascorbic } & \multicolumn{2}{c}{ With Ascorbic } \\
\cline { 2 - 5 } & Before & After & Before & After \\
\hline No. of animals & 7 & 7 & 7 & 7 \\
Body weight, Kg & $34.68 \pm 4.75$ & $33.83 \pm 4.72$ & $35.37 \pm 3.02$ & $34.16 \pm 3.05$ \\
Body weight loss, Kg & - & $1.22 \pm 0.18$ & - & $0.47 \pm 0.20$ \\
\hline
\end{tabular}

Table 3. Effect of ascorbic acid administration (mean \pm SEM) on thermal responses of sheep

\begin{tabular}{lccc}
\hline \multirow{2}{*}{ Items } & $\begin{array}{c}\text { Before } \\
\text { transportation }\end{array}$ & Without ascorbic & With ascorbic \\
\cline { 3 - 4 } No. of animals & 14 & 7 & 7 \\
Rectal temperature, $^{\circ} \mathbf{C}$ & $39.3 \pm 0.32 \mathrm{~b}$ & $39.7 \pm 0.16 \mathrm{a}$ & $39.4 \pm 0.28 \mathrm{~b}$ \\
Respiration rate/ $\mathbf{m i n}^{\text {Pulse rate/ } \text { min }}$ & $74.2 \pm 4.04 \mathrm{~b}$ & $96.5 \pm 10.7 \mathrm{a}$ & $84.1 \pm 15.4 \mathrm{ab}$ \\
\hline
\end{tabular}

a,b: Values with the different superscripts on the same column differ at $\mathrm{P}<0.05$

Table 4. Effect of ascorbic acid administration (mean \pm SEM) on hematological parameters of sheep

\begin{tabular}{|c|c|c|c|}
\hline \multirow{2}{*}{ Items } & \multirow{2}{*}{$\begin{array}{c}\text { Before } \\
\text { transportation }\end{array}$} & \multicolumn{2}{|c|}{ After transportation } \\
\hline & & With Ascorbic & Without Ascorbic \\
\hline $\begin{array}{l}\text { No. of animals } \\
\text { Red blood cells, } 10^{6} / \mu \mathrm{l}\end{array}$ & $\begin{array}{c}14 \\
9.88 \pm 2.44\end{array}$ & $\begin{array}{c}7 \\
10.62 \pm 3.61\end{array}$ & $\begin{array}{c}7 \\
9.18 \pm 3.28\end{array}$ \\
\hline Hematocrit (PCV) \% & $9.2 \pm 4.5$ & $10.38 \pm 4.66$ & $8.57 \pm 3.22$ \\
\hline Hemoglobin (g/dl) & $8.8 \pm 2.44$ & $10.0 \pm 0.61$ & $9.27 \pm 0.38$ \\
\hline Mean cell volume (MCV) & $37.0 \pm 1.22$ & $37.83 \pm 4.11$ & $37.0 \pm 1.41$ \\
\hline Mean cell volume (MCH) & $40.4 \pm 16.81$ & $41.33 \pm 14.22$ & $45.0 \pm 17.66$ \\
\hline $\begin{array}{l}\text { Mean corpuscular hemoglobin } \\
\text { concentration, } \mathrm{MCHC} \text { g/dl }\end{array}$ & $109.8 \pm 49.19$ & $112.66 \pm 46.31$ & $122.25 \pm 52.74$ \\
\hline White blood cells, $10^{3} / \mu \mathrm{l}$ & $9.58 \pm 2.82 b$ & $12.48 \pm 1.91 \mathrm{a}$ & $13.62 \pm 0.70 \mathrm{a}$ \\
\hline Neutrophils (\%) & $38.6 \pm 4.61$ & $39.66 \pm 4.62$ & $42.35 \pm 9.90$ \\
\hline Lymphocyte (\%) & $56.0 \pm 4.74$ & $54.5 \pm 4.56$ & $53.65 \pm 5.55$ \\
\hline Neutrophils / lymphocyte ratio & $0.698 \pm 0.14$ & $0.73 \pm 0.13$ & $0.80 \pm 0.23$ \\
\hline Monocyte (\%) & $3.4 \pm 0.54$ & $4.0 \pm 2.19$ & $2.25 \pm 0.5$ \\
\hline Eosinophil (\%) & $1.8 \pm 0.44$ & $1.83 \pm 0.40$ & $1.75 \pm 0.5$ \\
\hline Basophil (\%) & $0.0 \pm 0.0$ & $0.0 \pm 0.0$ & $0.0 \pm 0.0$ \\
\hline
\end{tabular}

a,b: Values with the different superscripts on the same column differ at $\mathrm{P}<0.05$ 
Table 5. Effect of ascorbic acid administration (mean \pm SEM) on some blood metabolites of sheep

\begin{tabular}{lccc}
\hline \multirow{2}{*}{ Items } & $\begin{array}{c}\text { Before } \\
\text { transportation }\end{array}$ & With ascorbic & Without ascorbic \\
\cline { 2 - 4 } No. of animals & 14 & 7 & 7 \\
Cortisol, $\mu \mathrm{g} / \mathrm{dl}$ & $13.28 \pm 1.10 \mathrm{~b}$ & $14.11 \pm 1.42 \mathrm{~b}$ & $16.50 \pm 1.62 \mathrm{a}$ \\
$\mathrm{T} 3, \mu \mathrm{g} / \mathrm{dl}$ & $1.46 \pm 0.35$ & $1.56 \pm 0.33$ & $1.81 \pm 0.47$ \\
$\mathrm{~T} 4, \mu \mathrm{g} / \mathrm{dl}$ & $4.81 \pm 1.09 \mathrm{a}$ & $3.46 \pm 1.18 \mathrm{~b}$ & $4.30 \pm 0.98 \mathrm{ab}$ \\
Total protein, g/dl & $6.7 \pm 0.95$ & $6.83 \pm 0.53$ & $6.87 \pm 0.31$ \\
Albumin, g/dl & $3.1 \pm 0.14$ & $3.14 \pm 0.14$ & $3.19 \pm 0.15$ \\
Globulin, g/dl & $3.61 \pm 1.00$ & $3.69 \pm 0.52$ & $3.66 \pm 0.43$ \\
Sodium, mmol/l & $133.87 \pm 5.02$ & $131.65 \pm 7.34$ & $132.65 \pm 6.70$ \\
Potassium, mmol/l & $4.85 \pm 0.43$ & $5.50 \pm 0.48$ & $5.03 \pm 0.52$ \\
Chloride, mmol/l & $102.37 \pm 4.42$ & $102.70 \pm 6.59$ & $103.97 \pm 5.36$ \\
ALT, U/l & $49.55 \pm 7.94 \mathrm{a}$ & $34.32 \pm 7.22 \mathrm{~b}$ & $32.21 \pm 8.67 \mathrm{~b}$ \\
AST, U/l & $155.55 \pm 4.25 \mathrm{a}$ & $139.5 \pm 3.11 \mathrm{~b}$ & $137.83 \pm 3.65 \mathrm{~b}$ \\
Urea, mg/dl & $29.73 \pm 4.35$ & $30.81 \pm 5.71$ & $30.10 \pm 6.52$ \\
Creatinine, mg/dl & $0.90 \pm 0.047 \mathrm{~b}$ & $0.93 \pm 0.018 \mathrm{~b}$ & $1.09 \pm 0.133 \mathrm{a}$ \\
Glucose, $\mathrm{mg} / \mathrm{dl}$ & $79.25 \pm 5.21 \mathrm{~b}$ & $68.65 \pm 6.38 \mathrm{ab}$ & $65.30 \pm 4.53 \mathrm{a}$ \\
Cholesterol, mg/dl & $73.79 \pm 7.22$ & $72.38 \pm 6.70$ & $72.07 \pm 5.78$ \\
Triglyceride, mg/dl & $47.06 \pm 8.51 \mathrm{a}$ & $37.96 \pm 9.33 \mathrm{~b}$ & $31.97 \pm 4.06 \mathrm{~b}$ \\
\hline
\end{tabular}

a,b: Values with the different superscripts on the same column differ at $\mathrm{P}<0.05$

\section{DISCUSSION}

After the 3-h. transportation, body weight loss and hematological blood parameters and blood metabolites, values were changed. Generally, ascorbic acid administration alleviated stress of transported sheep. Antioxidants such as ascorbic acid are free radical scavengers which protect the body defense system against excessively produced free radicals and stabilize health status of the animal. Ascorbic acid is a water soluble, extra-cellular, natural antioxidant and is involved in a number of oxidation and reduction reactions in the body (Sen, 2001 and Aya et al., 2006).

After the 3-h transportation, live weight loss was observed in the two groups but ascorbic acid alleviated live weight loss. Loss of live weight during transportation is most probably due to loss of water (dehydration) and deprivation of feed. High temperatures $\left(42-43 \pm 1{ }^{\circ} \mathrm{C}\right)$ during transportation might likely cause weight loss through loss of moisture from the respiratory tract. Warriss (1993) reported that animals can lose weight when they are subjected to greater energy demands, such as those needed to maintain balance or to thermoregulate in transport. Thermoregulation may involve greater loss of body water through sweating or panting. Average live weight losses in sheep ranged between 0.09 to $0.34 \%$ per hour (Thompson et al., 1987, and Warriss et al., 1987). In this study, live weight loss was greater than the previous studies which might be due to high ambient temperature.

Rectal temperature and respiration and pulse rates are recognized as important measures of physiological status (Lefcourt et al., 1986) as well as ideal indicators for assessment of stress in animals. The decreased rectal temperature and respiratory rates in ascorbic acid supplemented group compared with non-supplemented one indicated that supplementation of ascorbic acid ameliorated the heat stress in sheep. Ascorbic acid directly alters thermal set point by decreasing prostaglandin output, whose turnover increases during stress (Hadden et al., 1987) and which has a direct effect on the hypothalamic thermoregulatory zone (Ganong, 2001). Therefore, by affecting the prostaglandin output, this vitamin may have an ameliorating effect upon heat stressed animals.

After the 3-h transportation, values of hematological parameters were changed in the two groups but ascorbic acid group had highest red and white blood cells (Table 4) as a results of ascorbic acid administration. The increase in RBC count in the present study may be due to changes in erythrocyte osmotic fragility upon ascorbic acid administration. The result of Adenkola et al. (2009) and Adenkola et al. (2010) indicated that ascorbic acid protect membrane integrity of erythrocyte of livestock during stress. Consequently, exposure of sheep to heat stress (summer season) in this study resulted in an increase in packed cell volume (PCV). WBC counts after transportation was increase still within the normal range values in both groups. The change in WBC counts may be as a result of the release of Glucocorticoids during transportation, which is responsible for the trafficking and release of WBC from the bone marrow (Stanger et al., 2005, and Urban-Chmiel et al., 2009). Insignificant change in neutrophil/lymphocyte ratio obtained in the present study as a results of administered ascorbic acid after 3-h transportation showed that ascorbic acid ameliorated the stresses induced by transportation in sheep. Ascorbic acid's inhibitory role on cortisol. Also, ascorbic acid has been reported to be a chainbreaking antioxidant, involved in the prevention and restriction of free radical chain formation and propagation, consequently, protecting blood cells, including neutrophils and lymphocytes from oxidative damage (Powers and Jackson, 2008 and Urban-Chmiel et al., 2009). 
In the present study, transportation led to increased cortisol, T3, total protein, globulin, urea, creatinine, and lower T4, AST, ALT, triglycerides and cholesterol concentrations than before transportation in both groups. Three hours transportation decreased plasma aspartate aminotransferase (AST) and alanine aminotransferase (ALT) in sheep, but the decreases the values these enzymes are within the normal values (Duncan and Prasse, 1994). The decreases in these enzymes suggest that there is no liver damage but rather a slowdown of the function of the liver when the animals were subjected to transportation.

The increase of urea value found following 3-h. transportation in the present study might be due to feed deprivation and elevated cortisol concentration as established by several authors (Odore et al., 2004), and also as a result of increased protein degradation caused by hypoglycaemia. It has been shown that heat stress induces ascorbic acid depletion in the adrenal glands, and this is associated with corticosterone release (Sahota and Gillani, 1995).

The present results indicated that glucose concentrations values in the blood of sheep decrease as a results of transportation Sauberhich (1994) reported that glucose concentrations in animals subjected to stressful conditions, especially during road transportation recorded lower values.

Our results indicated that total cholesterol and triglycerides values were decreased after 3-h. transportation. In other studies, percentage reduction changes of total cholesterol and triglycerides upon vitamin C supplementation was 4.5 and $8.8 \%$, respectively (McRae, 2007 and 2008). In this study, percentage reduction of total cholesterol was 3.26 and $13.17 \%$ and triglycerides was 11.8 and $15.63 \%$ of vitamin $\mathrm{C}$ supplemented and non-supplemented groups, respectively. It has been found that vitamin C supplementation led to lowers serum low-density lipoprotein cholesterol and triglycerides (McRae, 2008). This means that body fat reserves are mobilized to provide energy during heat stress.

Non-significance differences in the values of sodium, potassium and chloride ions post 3-h transportation in ascorbic acid supplemented and non-supplemented sheep indicated that ascorbic acid administration as well as 3-h road transportation did not affect these important ions in sheep.

Generally, ascorbic acid administration alleviated stress effects of transported sheep through changes serum metabolites, values to normal values recorded before transportation

\section{CONCLUSION}

The results of the current study revealed that valuable effects of ascorbic acid administration on some physiological responses such as thermal and blood paramaters of sheep transported by road during the hot season. Therefore, ascorbic acid administration as anti-stress before transportation specially under hot season of sheep can be recommended.

\section{REFERENCES}

Adenkola, A.Y. and L.A. Durotoye, 2004. Haematological study during prepartum and postpartum periods in brown savanna does in Zaria, Nigeria. Proceedings $38^{\text {th }}$ Annual Conference Agricultural Society Nigeria, pp 538540

Adenkola, A.Y., J. O. Ayo, A.K.B. Sackey and A. B. Adelaiye, 2009. Haematological and serum biochemical changes in pigs administered with ascorbic acid and transported by road for four hours during the harmattan season. Journal Cell and Animal Biology, 3 (2): 21-28

Adenkola, A.Y., J.O. Ayo, A. K. B. Sackey and A. B. Adelaiye, 2010. Erythrocyte osmotic fragility of pigs administered antioxidant and transported by road for short-term duration during the harmattan season. African Journal Biotechnology, 9 (2): $226-233$

Ali, B. H. and A. A. Al-Qarawi, 2002. An evaluation of drugs used in the control of stressful stimuli in domestic animals: a review. Acta Veterinaria Brno, 71 (2): 205-216

Ali, B. H., A. A. Al-Qarawi and H. M. Mousa, 2006. Stress associated with road transportation in desert sheep and goats, and the effect of pretreatment with xylazine or sodium betaine. research veterinary science, 80 (3): 343-348

Ayo, J. O., N. S. Minka and M. Mamman, 2006. Excitability scores of goats administered ascorbic acid and transported during hot-dry conditions. Journal Veterinary Science, 7 (2): 127-131

Dantzer, R. and P. Mormede, 1983. Stress in farm animals: a need for re-evaluation. Journal of Animal Science, 57:6-18

Duncan, D. B., 1955. Multiple range and multiple Ftest. Biometrics, 11: 1

Duncan, J. R. and K.W. Prasse, 1994. Veterinary Laboratory Medicine. ( $3^{\text {rd }}$ Edition) Iowa state university press, Ames, 10

Farm Animal Welfare Council (FAWC), 2003. Farm Animal at Slaughter or Killing, Part 1, Defra Publication, Admail, London

Ferguson, D. M. and R. D. Warner, 2008. Have we underestimated the impact of pre-slaughter stress on meat quality in ruminants. Meat Science, 80 (1):12-19

Ganong, W. F., 2001. Text book of review of medical physiology. Lange Medical books/Mc Graw hill Medical Publishing division. pp. 246

Hadden, J. W., 1987. Neuroendocrine modulation of the thymus - dependent immune system. Annals of the New York Academy of Sciences, 496:39

Kadim, I. T., O. Mahgoub, A.Y., AlKindi2, W., AlMarzooqi1, N. M. Al-Saqri1, M. 3 Almaney, and I.Y. Mahmoud, 2007. Effect of transportation at high ambient temperatures on physiological responses, carcass and meat quality characteristics in two age groups of omani sheep. Asian-Australasian Journal of Animal Sciences, 20 (3): $424-431$ 
Lefcourt, A.M., J. Bitman, D.L. Wood and B. Stroud, 1986. Radiotelemetry system for continuously monitoring temperature in cows. Journal of Dairy Science, 69: 237-242

McRae, M. P., 2007. Vitamin C supplementation for treating hypercholesterolemia: a meta-analysis of 16 randiomized controlled trials. Journal of the American Nutraceutical Association, 10 (2): 21-8

McRae, M. P., 2008. Vitamin C supplementation lowers serum low-density lipoprotein cholesterol and triglycerides: a meta-analysis of 13 randomized controlled trials. Journal of chiropractic medicine, 7: 48-58

Minka, N.S. and J.O. Ayo, 2007. Physiological responses of transported goats treated with ascorbic acid during the hot-dry season: original article. Animal Science Journal, 78 (2): 164172

Minka, N.S. and J.O. Ayo, 2008. Haematology and behaviour of pullets transported by road and administered with ascorbic acid during the hotdry season. Research in Veterinary Science, 85 (2): 389-393

Minka, N.S. and J.O. Ayo, 2011. Modulating effect of ascorbic acid on transport-induced immunosuppression in goats. ISRN Veterinary Science, 2011: 10.5402/2011/749753

Nwe, T. M., E. Hori, M. Manda and S. Watanabe, 1996. Significance of catecholamines and cortisol levels in blood during transportation stress in goats. Small Ruminant Research, 20 (2): 129 135

Odore, R., A.D. Angelo, P. Badino, C. Bellino, S . Pagliasso, G. Re, 2004. Road transportation affects blood hormone levels and lymphocyte glucocotocoid and $\beta$-adrenergic receptors concentration in calves. Veterinary Journal, 168: $297-303$

Pardue, S. L., J. P. Thaxton and J. Brake, 1985. Role of ascorbic acid in chicks exposed to high environmental temperature. Journal of Applied Physiology 58: 1511 - 1516

Powers, S. K. and M. J. Jackson, 2008. Exerciseinduced oxidative stress: cellular mechanisms and impact on muscle force production. Physiological reviews, 88 (4): 1243-1276

Sahota, A.W. and A. H. Gillani, 1995. Effect of ascorbic acid supplementation on performance and cost of production in layers maintained under high ambient temperature. Pakistan Veterinary Journal, 15: 155- 158
Saidu, B., A.1. Ja'afaru, H.M. Ibrahim, U.M. Nuruddeen, O.M. Mamman, A.A. Abubakar, N.N. Pilau, A. Bello, N. Suleiman and B. Garba, 2012. Effect of diurnal variation and ascorbic acid administration on rectal temperature, pulse and respiratory rates in sheep during wet season in Sokoto. Scientific Journal of Veterinary Advances, 1(4): 117-119

Sauberhich, H. E., 1994. Pharmacology of vitamin C. Animal Reviews Nutrition, 14: 371 - 391

SAS, 1998. SAS User's guide: Statistics.S AS Inst. Inc., Cary,NC, Releigh.

Schaefer, A.L., S.D.M. Jones and R.W. Stanley, 1997. The Use of Electrolyte Solutions for Reducing Transport Stress. Journal of Animal Science, 75 (1): 258-265

Sen, C. K., 2001. Antioxidant in exercise, nutrition, sport and medicine, 31:891-908

Stanger, K. J., N. Ketheesan, A. J. Parker, C. J. Coleman, S. M. Lazzaroni and L. A. Fitzpatrick, 2005. The effect of transportation on the immune status of Bos indicus steers. Journal of Animal Science, 83 (11): 2632-2636

Thompson, J. M., W. J. O’Halloran, D. M. J. McNeil, N. J. Jackson-Hope and T. J. May, 1987. The effect of fasting on live weight and carcass characteristics in lambs. Meat Science, 20: 293309

Togun, V. A. and B. S. A. Oseni, 2005. Effect of low level inclusion of Biscuit dust in broiler finisher diet on pre-pubertal growth and some haematological parameters of unsexed broilers. Research Communications Animal Science, 1 (2): $10-14$

Urban-Chmiel, R., M. Kankofer, A.Wernicki, E. Albera, and A. Puchalski, 2009. The influence of different doses of $\alpha$-tocopherol and ascorbic acid on selected oxidative stress parameters in in vitro culture of leucocytes isolated from transported calves. Livestock Science, 127: 365-370

Warriss, P.D., S. N. Brown, E.A. Bevis, S. C. Kestin and C.S. Young, 1987. Influence of food withdrawal at various times preslaughter on carcass yield and meat quality in sheep. Journal of the Science of Food and Agriculture, 39: 325-334

Warriss, P. D., 1993. Ante-mortem factors which influence carcass shrinkage and meat quality. 39th International Congress of Meat Science and Technology. Calgary, Alberta, Canada, August 16, pp 51-65. 
تجريع الأغنام بفيتامين ج المضاد للإجهاد قبل النقل

أيمن يوسف كساب1، عبد الناصر أحمد محمد²

1- قسم الإنتاج الحيواني ، كلية الزراعة بالوادى الجليد ، جامعة اسيوط، 2- قسم الإنتاج الحيواني ، كلية النزراعة ، جامعة أسيوط

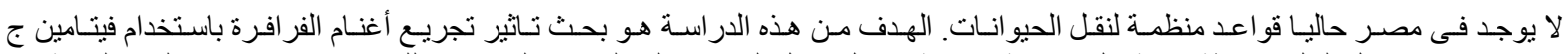

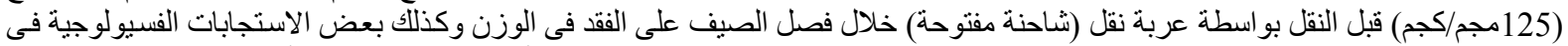

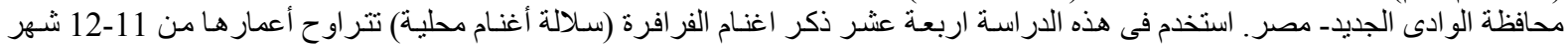

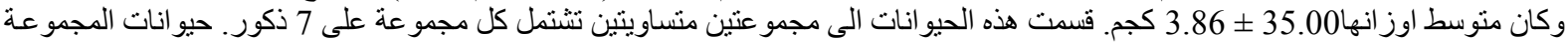

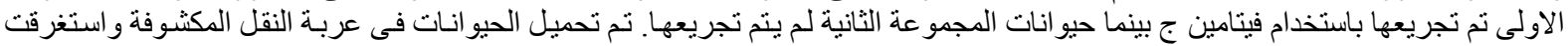

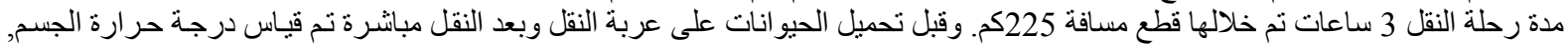

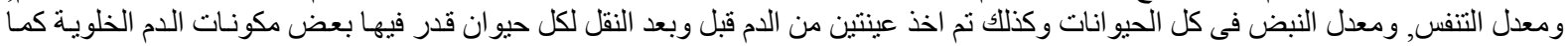

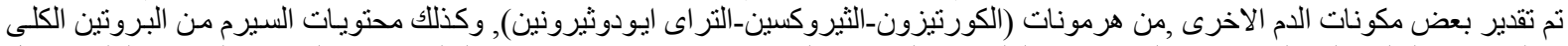

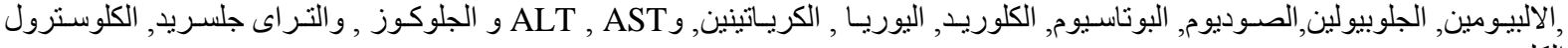

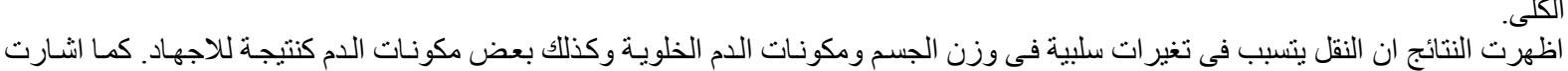

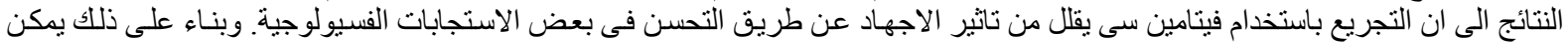

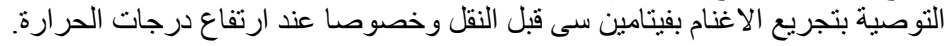

